\title{
Effect of Culcasia falcifolia on the biogenic amine levels in the brain tissue of pentylenetetrazole induced seizure in mice
}

\author{
Gracelyn Portia Anthony Doss * and Ramesh Francis \\ Department of Biological sciences and Agriculture, University of Eastern Africa Baraton, P.O. Box 2500, 30100-Eldoret, \\ Kenya.
}

Publication history: Received on 01 April 2019; revised on 30 April 2019; accepted on 07 May 2019

Article DOI: https://doi.org/10.30574/gscbps.2019.7.2.0062

\begin{abstract}
In the present study the effect of the ethanol extract of Culcasia falcifolia on the neurotransmitter levels were evaluated. Pentylenetetrazole (PTZ) (60 mg/kg body weight, i. p) was administered to all the groups of mice to induce convulsions. After observing the convulsion, all groups rats were sacrificed, whole brain was dissected out and separated the forebrain. The brain tissue was homogenized and then centrifuged. The aqueous phase was taken for the assay. The reading was obtained using spectroflurimeter. The result of the present study shows that the ethanol extract of $C$ ulcasia falcifolia at the dose of 200 and $400 \mathrm{mg} / \mathrm{kg}$ body weight significantly increased the level of inhibitory neurotransmitter GABA and also showed significant increase in the levels of dopamine, noradrenalin and serotonin when compared to seizure control group (PTZ treated group) and was almost equivalent to control group. The findings of the study showed that the extract at 200 and $400 \mathrm{mg} / \mathrm{kg}$ body weight significantly $(\mathrm{p}<0.001)$ increased the levels of GABA, dopamine, serotonin and noradrenaline. The ethanol extract of Culcasia falcifolia exerted antiepileptic activity by decreasing seizure susceptibility to pentylenetetrazole-induced seizure in mice due to restoration of GABA, serotonin, dopamine and noradrenaline concentration levels in mice brain.
\end{abstract}

Keywords: Culcasia falcifolia; neurotransmitter; epilepsy; Pentylenetetrazole

\section{Introduction}

Culcasia is a genus of flowering plants in the Araceae family, native to tropical Africa. Araceae is family of monocotyledonous flowering plants in which flowers are borne on a type of inflorescence called a spadix. The spadix is usually accompanied by, and sometimes partially enclosed in, a spathe or leaf-like bract. Also known as the arum family, members are often colloquially known as aroids [1]. Culcasia falcifolia is a medicinal plant which is traditionally used in Nandi County, Kenya in the treatment of epilepsy. The leaves of Culcasia falcifolia is used as ash (internal) for epilepsy [2] Culcasia falcifolia is a perennial climber, epiphytic on trees and growing to several meters, stem with adventitious roots, penetrating bark with short clasping roots at the nodes. The leaves are oblong, leathery, dark glossy green. The plant is native to damp evergreen forest in shade; riverine and swamp forests; marshy forest. It is found in Kenya, Ethiopia, Malawi, Tanzania, Uganda, Zambia and Zimbabwe [1]. There is no scientific documentation of the antiepileptic activity of Culcasia falcifolia till date. The present study aimed at evaluating the neuroprotective effects of Culcasia falcifolia in the treatment of epilepsy. Epileptic seizures are caused by a sudden imbalance between the inhibitory and excitatory signals in the brain with gamma amino butyric acid (GABA), noradrenaline, serotonin, and dopamine respectively, being the most important neurotransmitters involved [3]. Many studies have shown the implication of dopamine and serotonin in the pathophysiology of seizures. Biochemical evidences shows serotonergic mechanisms to the regulation of activities such as sleep and body temperature, as well as to the pathophysiology of human illness such as epilepsy and Parkinson's disease. In humans, decreased activity of noradrenaline and dopamine

\footnotetext{
${ }^{*}$ Corresponding author

E-mail address: gprf.bio@gmail.com
} 
has been found in some epileptic patients [4]. Noradrenergic and/or serotonergic deficits, may contribute to predisposition to epilepsies. Pharmacological studies show that noradrenergic and/or serotonergic transmissions are anticonvulsant. Through studies of innate pathophysiology, noradrenergic and serotonergic deficits have been identified in animal models of epilepsy, as well as in some humans with epilepsy. Increments of either noradrenalin or serotonin transmission can prevent seizure occurrence, whereas reduction will have the opposite effect. Spontaneous and experimentally induced deficiencies in noradrenaline, dopamine and serotonin have been implicated in the onset and perpetuation of seizure. Experimental procedures designed to increase neurotransmitter levels have proven antiepileptic properties [5]. Many studies have shown the effect of plant extracts on the neurotransmitter levels on the brains of PTZ induced seizures in mice. Studies on the effect of ethanol extracts of Guettarda speciosa on biogenic amines concentrations in rat brain after induction of seizures by PTZ showed significant increase in the monoamines in forebrain of rats. Thus, the study suggests that ethanol extract of Guettarda speciosa increased the monoamines on rat brain, which possibly decreased the susceptibility to PTZ induced seizure in rats [6].

\section{Material and methods}

\subsection{Collection of material}

The leaves were collected and washed with tap water to remove dusts and other unwanted materials accumulated on the leaves from their natural environment. The dust free leaves were allowed to dry under shade in the laboratory for two weeks. The dried leaves were powdered using laboratory electric blender to obtain a powder. The powdered leaf was further passed through a sieve to obtain finer particles. The leaf sample was stored in a clean dry labeled glass beaker until needed for extract preparation and analysis.

\subsection{Extract preparation}

To prepare the ethanol extract, using maceration method, 100 grams of powdered leaf sample of Culcasia falcifolia was mixed at ratio of 1 to 5 with ethanol $80 \%$ and kept at room temperature, with occasional stirring. Then, the solution was transferred to a percolator. The tab of the percolator released 2-3 drops of the solution per minute. After filtration, it was maintained in a water bath at $40^{\circ} \mathrm{C}$ for $16 \mathrm{~h}$ to let the alcohol be evaporated from the filtered solution to reach a final concentration of 50\%. It was then stored in sterile universal glass bottle [7].

\subsection{Experimental animals}

Male Swiss albino mice weighing between 20-25 grams were used for the study. The animals were placed in polypropylene cages with paddy husk as bedding. Animals were housed at a temperature of $24 \pm 2^{\circ} \mathrm{C}$ and relative humidity of $30-70 \%$. A 12:12 light: day cycle was followed. All animals were supplied water and food ad libitum. All the experimental procedures and protocols used in this study were reviewed and approved by the Institutional Animal Ethics Committee and were in accordance with the guidelines of the CPCSEA.

\subsection{Drugs and chemicals}

Sodium acetate buffer iodine solution; Acetic acid; sodium sulphate solution; trichloro-acetic acid; O-Phthalaldehyde (OPT) reagent; copper tartrate reagent. All chemicals were purchased from Sigma Aldrich USA.

\subsection{Brain homogenate preparation}

Pentylenetetrazole (PTZ) (60 mg/kg body weight, i. p) was administered to all the groups to induce clonic convulsions. PTZ was administered 60 minutes after the administration of the two doses (200 and $400 \mathrm{mg} / \mathrm{kg} \mathrm{b}$. wt.) ethanol extract of Culcasia falcifolia to group III and IV. And 30 minutes after the administration of diazepam to group II. Following the administration of PTZ, mice were placed in separate cages and were observed for the occurrence of seizures, initially for 30 minutes and later up to 24 hours.

On the $14^{\text {th }}$ day after observed the convulsion all groups rats were sacrificed, whole brain was dissected out and separated the forebrain [8]. The brain tissue was homogenized in $5 \mathrm{ml} \mathrm{HCl-butanol} \mathrm{for} \mathrm{about} 1 \mathrm{~min}$. The sample was then centrifuged for $10 \mathrm{~min}$ at 2000 r.p.m. An aliquot supernatant phase $(1 \mathrm{ml})$ was removed and added to centrifuge tube containing $2.5 \mathrm{ml}$ heptane and $0.3 \mathrm{ml} \mathrm{HCl}$ of $0.1 \mathrm{M}$. After $10 \mathrm{~min}$ of vigorous shaking the tube was centrifuged for 10 minutes at 2000 r.p.m in order to separate the two phases, and the overlaying organic phase was removed. The aqueous phase was taken for the assay. The reading was obtained using spectroflurimeter ([9). 


\subsection{Estimation of noradrenaline and dopamine}

To the $0.2 \mathrm{ml}$ of aqueous phase, $0.05 \mathrm{ml} 0.4 \mathrm{M} \mathrm{HCl}$ and $0.1 \mathrm{ml}$ of Sodium acetate buffer (pH 6. 9) were added, followed by $0.1 \mathrm{ml}$ iodine solution ( $0.1 \mathrm{M}$ in ethanol) for oxidation. The reaction was stopped after $2 \mathrm{~min}$ by addition of $0.1 \mathrm{ml}$ sodium sulphate solution. $0.1 \mathrm{ml}$ acetic acid is added after $1.5 \mathrm{~min}$. The solution was then heated to $100^{\circ} \mathrm{C}$ for $6 \mathrm{~min}$ when the sample again reached room temperature, excitation and emission spectra were read from the spectrofluorimeter. The readings were taken at 330-375 $\mathrm{nm}$ for dopamine and 395-485 $\mathrm{nm}$ for noradrenaline [9].

\subsection{Estimation of Serotonin}

To $0.2 \mathrm{ml}$ aqueous phase and $0.25 \mathrm{ml}$ of O-Phthalaldehyde (OPT) reagent was added. The fluorophore was developed by heating the mixture at $100^{\circ} \mathrm{C}$ for $10 \mathrm{~min}$. After the samples reached equilibrium with the ambient temperature, readings were taken at $360-470 \mathrm{~nm}$ in the spectrofluorimeter. $0.25 \mathrm{ml}$ concentrated. $\mathrm{HCl}$ without OPT was added to serotonin tissue blank [9].

\subsection{Estimation of GABA}

A sample $(0.1 \mathrm{ml})$ of tissue extract was placed in $0.2 \mathrm{ml}$ of $0.14 \mathrm{M}$ ninhydrin solution in $0.5 \mathrm{M}$ carbonate-bicarbonate buffer ( $\mathrm{pH}$ 9.95), kept in a water bath at $60^{\circ} \mathrm{C}$ for 30 minutes, then cooled at room temperature and treated with $5 \mathrm{ml}$ of copper tartrate reagent $(0.16 \%$ disodium carbonate, $0.03 \%$ copper sulphate and $0.0329 \%$ tartaric acid). After 10 min, fluorescence at $377 / 455 \mathrm{~nm}$ in a spectofluorimeter was recorded [10].

\subsection{Statistical analysis}

The data were expressed as mean \pm standard error mean (S.E.M).The Significance of differences among the group was assessed using one way analysis of variance (ANOVA). The test followed by Dunnett's test p values less than 0.01 were considered as significance.

\section{Results and discussion}

The levels of GABA in the PTZ treated group was decreased $(195.27 \pm 2.53 \mathrm{~ns})$ when compared to the control group (298.41 \pm 2.49$)$. The extract pretreated groups at the doses of 200 and $400 \mathrm{mg} / \mathrm{kg}$ body weight significantly (p<0.01) increased the GABA levels $(248.52 \pm 1.73$ and $274.29 \pm 1.49)$ when compared to PTZ $(195.27 \pm 2.53)$.

Table 1: Effects of the ethanol extract of Culcasia falcifolia and standard drug diazepam on GABA and serotonin concentrations levels in the brain tissue of Pentylenetetrazole-induced seizure in mice

\begin{tabular}{|c|c|c|c|c|c|}
\hline Group & Drug treatment & $\begin{array}{l}\text { GABA } \\
\text { Picogram/mg } \\
\text { of wet tissue }\end{array}$ & $\begin{array}{l}\text { Serotonin } \\
\text { Picogram/mg } \\
\text { of wet tissue }\end{array}$ & $\begin{array}{l}\text { Dopamine } \\
\text { Picogram/mg } \\
\text { of wet tissue }\end{array}$ & $\begin{array}{l}\text { Noradrenaline } \\
\text { Picogram/mg } \\
\text { of wet tissue }\end{array}$ \\
\hline Group I & $\begin{array}{l}\text { control } \\
0.1 \% \mathrm{CMC}\end{array}$ & $298.41 \pm 2.49$ & $203.1 \pm 1.31$ & $824.10 \pm 2.43$ & $696.62 \pm 3.57$ \\
\hline Group II & $\begin{array}{l}\text { PTZ (SCMC) } \\
1 \mathrm{ml} / 100 \mathrm{gms}\end{array}$ & $195.27 \pm 2.53^{\mathrm{ns}}$ & $107.5 \pm 2.37^{n s}$ & $522.41 \pm 3.24^{\mathrm{ns}}$ & $437.17 \pm 2.63^{\mathrm{ns}}$ \\
\hline Group III & $\begin{array}{l}\text { Diazepam }(5 \mathrm{mg} / \mathrm{kg})+ \\
\text { PTZ } 60 \mathrm{mg} / \mathrm{kg}\end{array}$ & $286.54 \pm 2.58^{* *}$ & $164.54 \pm 1.46^{* *}$ & $867.31 \pm 4.42^{* *}$ & $629.83 \pm 2.34^{* *}$ \\
\hline Group IV & $\begin{array}{l}\text { EECF }(200 \mathrm{mg} / \mathrm{kg})+ \\
\text { PTZ } 60 \mathrm{mg} / \mathrm{kg}\end{array}$ & $248.52 \pm 1.73^{* *}$ & $117.24 \pm 2.44^{* *}$ & $703.21 \pm 3.27^{* *}$ & $573.61 \pm 2.26^{* *}$ \\
\hline Group V & $\begin{array}{l}\text { EECF }(400 \mathrm{mg} / \mathrm{kg})+ \\
\text { PTZ } 60 \mathrm{mg} / \mathrm{kg}\end{array}$ & $274.29 \pm 1.49^{* *}$ & $153.68 \pm 3.28^{* *}$ & $791.48 \pm 2.32^{* *}$ & $707.42 \pm 4.71^{* *}$ \\
\hline
\end{tabular}

Note: EECF: ethanol extract of Culcasia falcifolia; Comparison between a- group I vs. group II; b- group III vs. group IV and group V; Values are expressed as mean \pm SEM; ns- non significant, $p<0.01^{* *}$, Statistical significant test by ANOVA, followed by Dunnett's t' test

The levels of serotonin in the PTZ treated group was decreased (107.5 \pm 2.37$)$ when compared to the control group (203.1 \pm 1.31 ). The extract pretreated groups at the doses of 200 and $400 \mathrm{mg} / \mathrm{kg}$ body weight significantly (p<0.01) increased the serotonin levels $(117.24 \pm 2.44$ and $153.68 \pm 3.28)$ when compared to PTZ (107.5 \pm 2.37$)$. The levels of dopamine in the PTZ treated group was decreased (522.41 \pm 3.24$)$ when compared to the control group (824.10 \pm 2.43$)$. 
The extract pretreated groups at the doses of 200 and $400 \mathrm{mg} / \mathrm{kg}$ body weight significantly $(\mathrm{p}<0.01)$ increased the dopamine levels (703.21 \pm 3.27 and 791.48 \pm 2.32$)$ when compared to PTZ (522.41 \pm 3.24$)$. The levels of noradrenaline in the PTZ treated group was decreased (437.17 \pm 2.63$)$ when compared to the control group (696.62 \pm 3.57$)$. The extract pretreated groups at the doses of 200 and $400 \mathrm{mg} / \mathrm{kg}$ body weight significantly $(\mathrm{p}<0.01)$ increased the dopamine levels (573.61 \pm 2.26 and $707.42 \pm 4.71)$ when compared to PTZ $(437.17 \pm 2.63)$.

Epilepsy may develop because of an imbalance of nerve signalling chemicals called neurotransmitters. In case of epilepsy, there may be abnormally high level of excitatory neurotransmitters (glutamate) that increase neuronal activity, while abnormally low level of inhibitory neurotransmitters (GABA) that increase neuronal activity in the brain. GABA hypoactivity and glutamate hyperactivity can enhance an epileptic seizure. In epileptic foci GABA hypo activity, which reduces the activity of dopaminergic neurons through a presynaptic effect through GABAA receptors. At low doses, noradrenaline can enhance epileptic seizures, whereas at high doses, it has a protective effect on seizures. Glutamate hyperactivity is exerted through presynaptic N- methyl- D- aspartate receptors, which strongly inhibit serotoninergic neurons and through post synaptic ionotropic glutaminergic receptors, which can induce epileptic seizures [11]. The result of the present study shows that the ethanol extract of Culcasia falcifolia at the dose of 200 and $400 \mathrm{mg} / \mathrm{kg}$ body weight significantly increased the level of inhibitory neurotransmitter GABA and also showed significant increase in the levels of dopamine, noradrenalin and serotonin when compared to seizure control group (PTZ treated group) and was almost equivalent to control group. GABA is a major inhibitory neurotransmitter of CNS and increase in its level in brain has variety of CNS dependent effects including anticonvulsant effect. In addition to the GABA binding site, the GABAA receptor complex appears to have distinct allosteric binding sites for benzodiazepines, barbiturates. Many drugs that increase the brain contents of GABA have exhibited anticonvulsant activity against seizures induced [12]. Slight deficiencies in GABAergic transmission may lead to hyper excitability and pathological neuronal discharges leading to epilepsy. GABA is an endogenous agonist at GABAA receptor (ionotropic receptor) thereby opening the channels to $\mathrm{Cl}$ - ions in the neuronal membrane [13]. The extract showed significant increase GABA content in brain. This suggests that the anticonvulsant activity of Culcasia falcifolia extract is probably through elevation of brain GABA content. The increase in the serotonergic transmission raises the threshold of Pentylenetetrazole (PTZ) induced seizures in many animal test systems, thereby protecting against PTZ induced convulsions [14]. The brain serotonin is thought to have an epileptic effect and antidepressant drugs-like selective serotonin reuptake inhibitorshave proved to be useful in seizure control [15]. Noradrenaline has also a role to play in the control of seizures, but less significantly when compared with other biogenic amines, as it is mainly concerned with blood pressure regulation [16]. Barringtonia acutangula (L.) ethanol leaf extract increased the levels of monoamines such as NA, DA \& 5-HT significantly in rat's forebrain. The extract increased the seizure threshold and decreased the susceptibility to MES induced seizure in rats. The study suggested that ethanol extract of leaves of Barringtonia acutangula (L.) possess antiepileptic properties that may be due to restored biogenic amines in rat brain [12]. The methanol extract of Oxalis corniculata significantly restored the decreased levels of brain NA, DA, 5-HT and GABA in mice brain. The study suggested that methanol extract of $O$. corniculata L. increased the levels of biogenic amine on rat brain, which may be decreased the susceptibility to PTZ induced seizure in rats. Similarly, the findings of the present study suggests that the antiepileptic activity offered by the ethanol extract of Culcasia falcifolia against Pentylenetetrazole-induced seizure may be due to the increase in GABA, noradrenaline, dopamine and serotonin levels in mice[17]. In the present study the ethanol extract of Culcasia falcifolia decreased seizure susceptibility to Pentylenetetrazole-induced seizure in mice due to restoration of GABA, serotonin, dopamine and noradrenaline concentration levels in mice brain.

\section{Conclusion}

The findings of the present study concludes that the ethanol extract of Culcasia falcifolia exerted antiepileptic activity by decreasing seizure susceptibility to Pentylenetetrazole-induced seizure in mice due to restoration of GABA, serotonin, dopamine and noradrenaline concentration levels in mice brain.

\section{Compliance with ethical standards}

\section{Acknowledgments}

The authors are grateful for all the support provided to carry out the research.

\section{Disclosure of conflict of interest}

No conflict of interest 


\section{Statement of ethical approval}

The present study was approved by the Institutional Research and Ethical Committee of the University of Eastern Africa Baraton, Kenya

\section{References}

[1] Ghogue JP and Ali M. (2010). Culcasia falcifolia. The IUCN Red List of Threatened Species http://dx.doi.org/10.2305/IUCN.UK.2010 3.RLTS.

[2] Pascaline J, Catherine L, George O, Dennis O and Charles M. (2007). Herbal Treatments in Aldai and Kaptumo Divisions in Nandi District, Rift Valley Province, Kenya. African Journal of Traditional and Complementary and Alternative Medicine, 5(1), 103-105.

[3] Rang HP, Dale MM, Ritter JM and Moore PK. (2007). Pharmacology, $6^{\text {th }}$ ed. Churchill Livingstone, Edinburgh PP 457-475.

[4] Bagdy G, Kecskemeti V, Riba P, and Jakus R. (2007). Serotonin and epilepsy. Journal of Neurochemistry, 100, 857873.

[5] Clinckers R, Smolders I, Meurs A, Ebinger G and Michotte Y. (2005). Hippocampal dopamine and serotonin elevations as pharmacodynamic markers for the anticonvulsant efficacy of oxcarbazepine and 10, 11- dihydro10-hydroxycarbamazepine. Neuroscience Letters, 390, 4853.

[6] Kumar AS and Gandhimathi. (2009). Effect of Guettarda speciosa extracts on biogenic amines concentrations in rat brain after induction of seizure. International Journal of Pharmacy and Pharmaceutical Sciences, 1(1), 237243.

[7] Heidari MR and Abbasifard M. (2002). Evaluation of the analgesic effect of Brassica nigra in mice. Journal of Mazandaran University of Medical Sciences, 12, 18-26.

[8] Fisher RS. (1989). Animal models of the epilepsies. Brain Research Reviews, 14, 245-78.

[9] Schlumpf M, Lichtensteiger W, Langemann H, Waser PG, and Hefti F. (1974). A fluorimetric dopamine micromethod for the simultaneous determination of serotonin, noradrenaline and in milligram amounts of brain tissue. Biochemical Pharmacology, 23, 237-46.

[10] Lowe IP, Robins E and Eyerman GS. (1958).The fluorimetric measurement of glutamic decarboxylase measurement and its distribution in brain. Journal of Neurochemistry, 3, 8- 18.

[11] Tripathi KD. (2013). Essentials of medical pharmacology, Jaypee brothers medical publishers (p) ltd, $6^{\text {th }}$ edition, 401-402.

[12] Sandhyarani G, Swathi K, Gangarapu K, and Praveen K. (2014). Screening of phytochemical and role of Barringtonai acutangula extract on biogenic amines concentration in rat brain. Asian journal of pharmaceutical science and technology, 1(1), 61-64.

[13] Katzung B, Masters SB, and Trevor AJ. (2012). Basic \& clinical pharmacology. New York: McGraw-Hill Medical. Chapter 24 Antiseizure drugs, 403-426

[14] Srinivasan KK, Aleykutty NA, and Rao PG. (1993). Diuretic and antilithiatic activity of Dendrophthoe falcata. Fitoterapia, 4, 325-31.

[15] Abdel-Reheim E and Mohamed T. (2008): Modulatory effects of pumpkin seed oil on pilocarpine - model of epilepsy in rats compared to topiramate as a common antiepileptic drug. Journal of the Egyptian German Society of Zoology, 57C, 151-195.

[16] Saravana A and Gandhimathi R. (2009). Study on phytochemical profile and antiepileptic activity of inner bark of Guettarda speciosa (L.). Journal of Pharmaceutical Sciences and Research, 1(2), 61-66.

[17] Senthil D. (2013). Effect of Fagonia Cretica (L.) extracts on biogenic amines concentrations in rat brain after induction of Seizure. International Journal of Preclinical \& Pharmaceutical Research, 4(2), 81-84.

\section{How to cite this article}

Gracelyn Portia A and Ramesh F. (2019). Effect of Culcasia falcifolia on the biogenic amine neurotransmitter levels on the brain tissue of pentylenetetrazole induced seizure in mice. GSC Biological and Pharmaceutical Sciences, 7(1), 01-06. 